\title{
Development of Learning Media for Motorcycle Chassis Training Kit
}

\author{
Nurcholish Arifin Handoyono \\ Email : arifin@ustjogja.ac.id * \\ *: coresponndensing author \\ Universitas Sarjanawiyata Tamansiswa, Jl. Batikan UH-III/1043, Yogyakarta, Indonesia;
}

Article history

Received Jan 13, 2021

Revised May 21, 2021

Accepted May 31, 2021

Keywords

Chasis

Learning Media

Motorcycle

Training Kit
This research aims to determine the development process and the feasibility of learning media for motorcycle chassis training kit at SMK Muhammadiyah 1 Bambanglipuro. The type of research used is R\&D. The research subjects were 32 students of class X TBSM SMK Muhammadiyah 1 Bambanglipuro. The data collection instruments used observation and questionnaires. The data analysis technique used the evaluation criteria analysis to determine the feasibility of learning media. The results showed that: (1) The development process went through several stages, namely: (a) problem background; (b) problem identification; (c) development ideas; (d) pre-production stage (tools and materials); (e) production stage; (f) product development; (g) validation and revision; (h) feasibility test; and (i) wearable products; and; (2) Learning media for motorcycle chassis training kit are categorized as very suitable for use in learning with the results of validation of media experts by $90 \%$, material experts by $95 \%$, small group trial of $85.24 \%$, and large group trial of $83.94 \%$.

This is an open access article under the CC-BY-SA license.

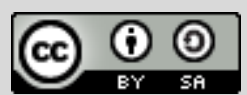

\section{Introduction}

The rapid development of science and technology affects the performance of the workforce needed by the increasing business and industry (Maryanti \& Apriana, 2019). To overcome this, vocational school is a level of education that has the aim of preparing graduates to be ready for work. Learning in SMK aims to develop the academic potential and personality of students. Besides, students are also required to master standard competencies by their vocational skills and apply attitude and professional values as a competent workforce, able to adapt to developments in technological science and be highly competitive (Sunarto \& Supriadi, 2019).

Muhammadiyah 1 Bambanglipuro Vocational School, especially the Department of Business and Motorcycle Engineering, is an educational institution that is tasked with organizing learning activities to produce quality graduates who are ready to compete in the era of the industrial revolution 4.0. Many efforts have been made to improve the quality of learning. This can be seen from the addition of student learning facilities, including renovation of study rooms, adding 
reading books in the library, learning media, and the addition of other facilities and infrastructure (Febriani \& Sarino, 2017; PH, 2013).

Motorcycle Chasis Subject is one of the subjects that must be mastered by every student, therefore students are expected to be able to understand and practice this knowledge in the world of work. The steering system and hydraulic brake system are part of the chassis system on a motorcycle. The material was delivered to class XI TBSM students for 8 hours each week at the Muhammadiyah 1 Bambanglipuro Vocational School.

Data from observations during apprenticeship 3 at the Muhammadiyah 1 Bambanglipuro Vocational School, in the Motorcycle Chasis subject, it was found that there were still many students who did not understand the material of steering systems and hydraulic brake systems on the motorcycle. This can be seen when students do individual practice for marking, namely when doing practice most students always ask or ask for help from other students.

The failure to achieve the learning objectives is caused by several factors such as the learning model which is still dominated by the lecture model, the lack of interaction between students and teachers, less conducive classroom conditions (Kurt, 2017). The limited resources available are also an obstacle due to the lack of learning tools such as teaching media in the form of teaching aids or training kits.

Learning media is one element that has an important role in the learning process to help achieve learning objectives (N. A. Handoyono \& Rabiman, 2020; Nurcholish Arifin Handoyono, 2019). Learning media has an important role in the learning process, namely clarifying the presentation of messages and information so that it can increase and direct student attention. With learning media, students can overcome the limitations of senses, space, and time (Azhar, 2011). Learning media can provide similar experiences to students about events in their environment.

The learning media for the steering system and hydraulic brake system used in the learning process are already available, but the numbers are still not by the number of students per class, whose average number is 30 students. Besides, learning media have been used too often for practicum, so that many components have been damaged, lost, and do not function normally. With these conditions, the learning media is not suitable for use in the learning process.

Based on the problems that have been disclosed, it can be concluded that it is necessary to develop learning media in the form of motorcycle chassis training kits which will focus on the steering system and hydraulic brake system. The learning media developed can be used for Motorcycle Chasis Subjects, so that it is expected to help solve the problem of the lack of adequate learning media at the Muhammadiyah 1 Bambanglipuro Vocational School. 


\section{Method}

This type of research is R\&D with 9 stages which can be seen as follows on Figure 1 (Sugiyono, 2014):

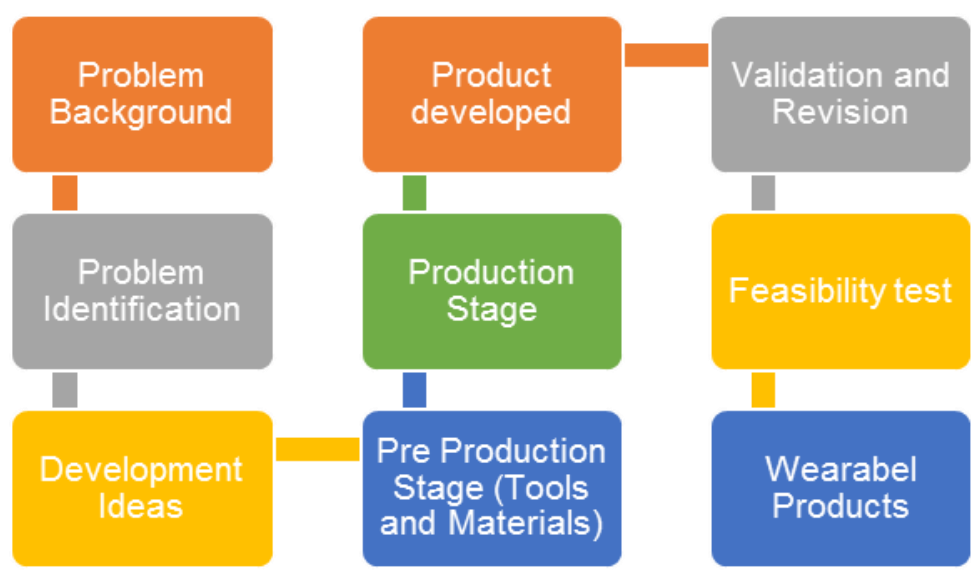

Figure 1. Development Stage

The research subjects used 32 students of class X Business Engineering and Motorbikes at Muhammadiyah 1 Bambanglipuro Vocational School.

The data collection instruments used observation and questionnaires. Observation is used to determine the need for instructional media on motorcycle chassis subjects, while the questionnaire uses a Likert scale consisting of 4 alternative answers, namely: 4 (very good), 3 (good), 2 (sufficient), and 1 (less) to measure the feasibility of the learning media being developed. The questionnaire contains a feasibility assessment by material experts, media experts, and students. The limited trial used 18 students, while the area test was 32 students.

The data analysis technique used evaluation criteria analysis to determine the percentage of the feasibility of learning media based on the results of a questionnaire with the following formula:

$$
\%=\frac{\text { Observed score }}{\text { Expected score }} \times 100 \%
$$

The results of the percentage of media feasibility were consulted with table 1 to determine the feasibility value of the media. The minimum value of the eligibility of the learning media set is in the "Good" category 
Table 1. Percentage Scale and Categories

\begin{tabular}{cc}
\hline Percentage & Categories \\
\hline $80 \%-100 \%$ & very good \\
$60 \%-79 \%$ & good \\
$50 \%-59 \%$ & sufficient \\
$<50 \%$ & less \\
\hline
\end{tabular}

\section{Result and Discussion}

The initial problem in learning motorcycle chassis is the limited learning media, especially on the steering system and hydraulic brakes. This media limitation causes students to have difficulty accepting abstract material (Nurcholish Arifin Handoyono \& Hadi, 2018). Based on these considerations, a learning media was developed in the form of a motorcycle chassis training kit.

The design of learning media for motorcycle chassis training kits is focused on the steering system and hydraulic brakes that are adjusted to the material on the subject of motorcycle chassis. The learning media criteria developed were: (1) easy to use; (2) attractive design; (3) economical in terms of financing and manufacturing without compromising the quality of the training kit; (4) can be used in learning to study motorbike steering systems and hydraulic brake systems.

Initial product specifications developed using the Suzuki Satria FU motorcycle components as the main components of the steering system and hydraulic brake system. The initial design of the developed training kit can be seen on Figure 2:

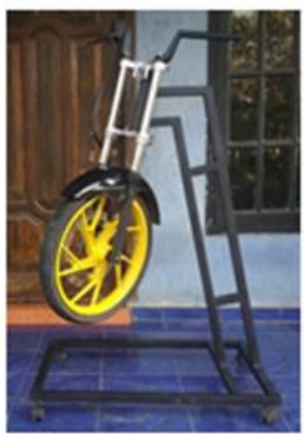

(a)

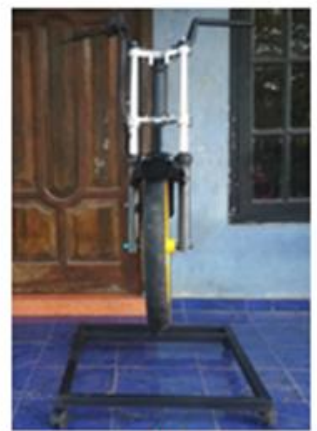

(b)

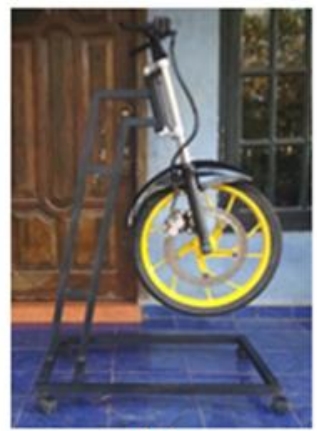

(c)

Figure 2. Product Training Kit Display: (a) Left; (b) Font; (c) Right

The initial design was consulted with media experts, material experts, and small group trials to measure the feasibility of the training kit that had been developed. Based on the feasibility results of the media experts, an average of $90 \%$ is categorized as very good, $95 \%$ of the material experts are categorized as very good, and from the small group trial, $85.24 \%$ is categorized as very good. The results of the feasibility of learning media that have been developed in detail can be seen on Figure 3: 


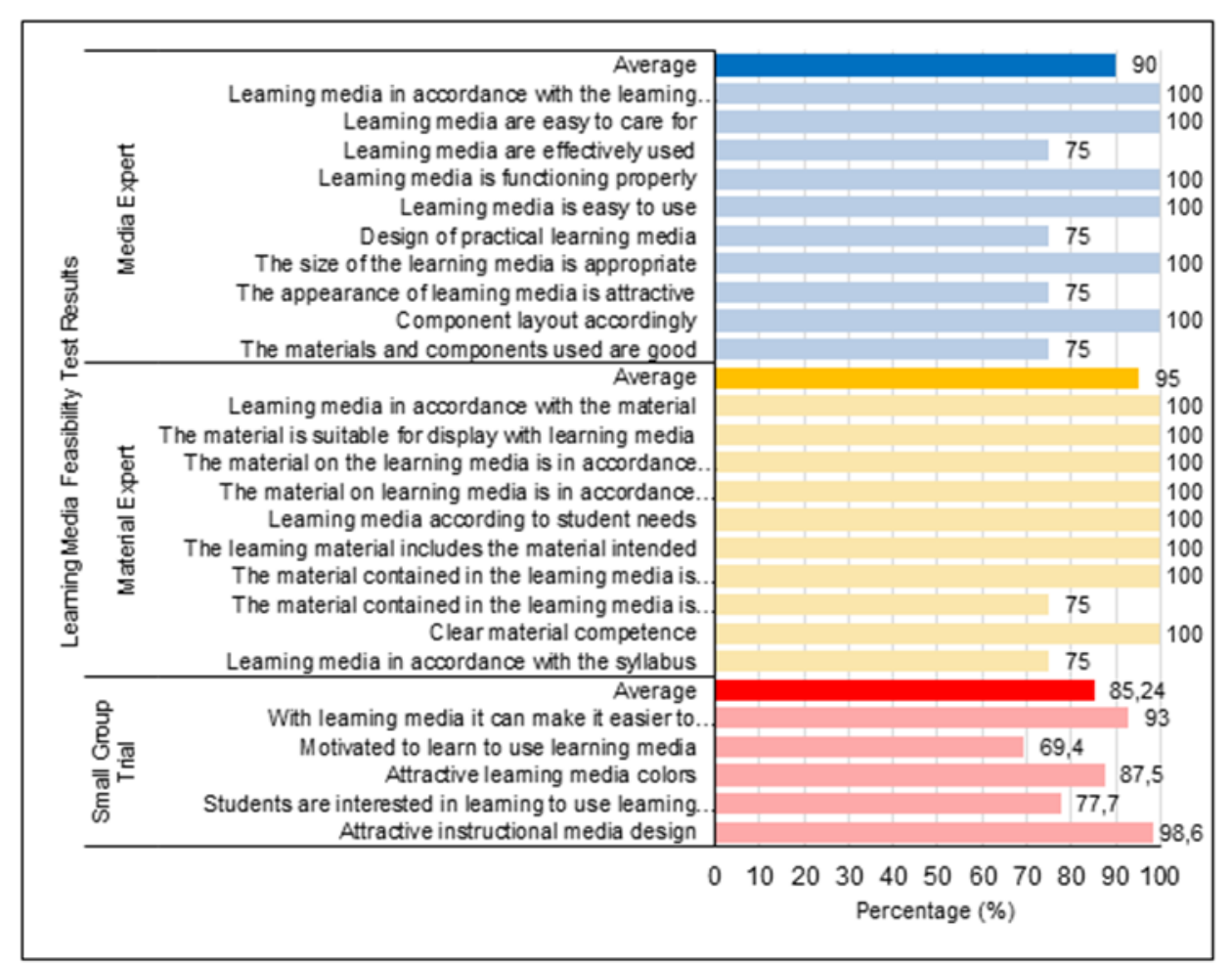

Figure 3. Feasibility Results of Learning Media by Media Experts, Material Experts, and Small Group Trial

Revision of instructional media products refers to suggestions obtained from material experts and media experts so that they will produce appropriate learning media when used in the learning process. The following are the inputs that have been submitted on table 2:

Table 2. Revision Results Based on Suggestions from Media Expert and Material

\begin{tabular}{|c|c|c|c|c|}
\hline $\begin{array}{l}\text { Suggestion } \\
\text { form }\end{array}$ & Revision & Before & After & Revised Form \\
\hline $\begin{array}{l}\text { Media } \\
\text { Expert }\end{array}$ & $\begin{array}{l}\text { Includes job sheets } \\
\text { for instructional } \\
\text { media for trainer } \\
\text { steering systems } \\
\text { and motorcycle } \\
\text { hydraulic brake } \\
\text { systems. }\end{array}$ & $\begin{array}{l}\text { There is not yet a job } \\
\text { sheet for instructional } \\
\text { media for trainers for } \\
\text { steering systems and } \\
\text { motorcycle hydraulic } \\
\text { brake systems. }\end{array}$ & $\begin{array}{lr}\text { Job sheets } & \text { are } \\
\text { available } & \text { for } \\
\text { instructional medla } \\
\text { for trainer steering } \\
\text { systems } \\
\text { motorcycle and } \\
\text { hydraulic brake } \\
\text { systems }\end{array}$ & 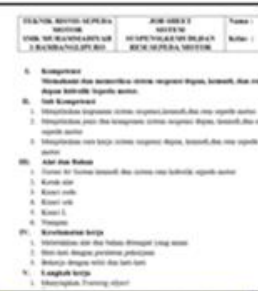 \\
\hline \multirow[t]{2}{*}{$\begin{array}{c}\text { Material } \\
\text { Expert }\end{array}$} & $\begin{array}{l}\text { Gives a handgrip } \\
\text { on the steering } \\
\text { handlebar }\end{array}$ & $\begin{array}{l}\text { Not yet available } \\
\text { handgrip on the } \\
\text { steering handlebar }\end{array}$ & $\begin{array}{l}\text { Has available } \\
\text { handgrip on the } \\
\text { steering handlebar }\end{array}$ & \\
\hline & $\begin{array}{l}\text { Providing work } \\
\text { methods along with } \\
\text { hydraulic brake } \\
\text { system } \\
\text { components in the } \\
\text { form of cards }\end{array}$ & $\begin{array}{l}\text { There is no working } \\
\text { method along with } \\
\text { the hydraulic brake } \\
\text { system components } \\
\text { in the form of a card }\end{array}$ & $\begin{array}{l}\text { Already available } \\
\text { how to work along } \\
\text { with hydraulic } \\
\text { brake system } \\
\text { components in the } \\
\text { form of cards }\end{array}$ & \\
\hline
\end{tabular}


The final product results from the training kit after being revised are then used in the learning process, namely in large group trials. The final product results can be seen as follows on Figure 4:

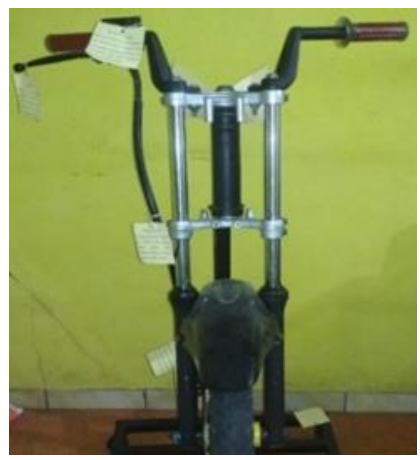

Figure 4. Final Product Result of Motorcycle Chasis Training Kit

The results of the large group trial obtained an average of $83.94 \%$ which were categorized as very good with the following details on Figure 5:

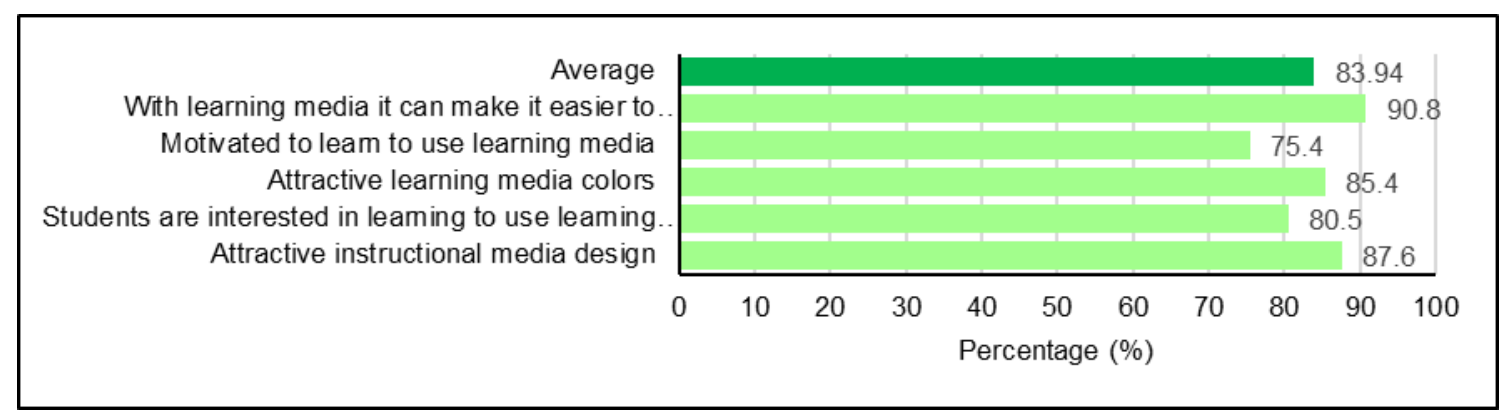

Figure 5. Feasibility Results of Learning Media by Large Group Trial

Based on the results of the large group trial, it can be concluded that the learning media developed in the form of a motorcycle chassis training kit is suitable for use in learning. Learning media developed can enrich the material in learning (Sudarsono, 2020) (Smaldino, Lowther, \& Mims, 2015). The use of media in the learning process can be a solution to facilitate the delivery of material so that the learning process becomes effective and efficient which will make learning objectives easier to achieve.

The result of the research is that the motorcycle chassis learning media which is expected to produce the resulting development products can be a means of helping teachers to deliver material to students so that learning becomes more interesting, efficient, and effective. Learning media that have been developed can be combined as a means in student-centered active learning models such as problem-based learning or inquiry learning (Nurcholish Arifin Handoyono \& Arifin, 2016) so that the quality of learning outcomes can be improved and also reduces the burden on teachers in delivering material continuously. 


\section{Conclusion}

The development process goes through several stages, namely: (1) Problem Background; (2) Problem Identification; (3) Development Ideas; (4) Pre-Production Stage (Tools and Materials); (5) Production Stage; (6) Product Development; (7) Validation and Revision; (8) Feasibility Test; and (9) Wearable Products. Learning media for motorcycle chassis training kits are categorized as very feasible to use in learning with the results of validation of media experts by $93.25 \%$, material experts by $95 \%$, small group trial of $85.27 \%$, and large group trial of $82.75 \%$. 


\section{References}

Azhar, A. (2011). Media Pembelajaran. In Media Pembelajaran. Jakarta: Raja Grafindo Persada.

Febriani, P. S., \& Sarino, A. (2017). Dampak Cara Belajar dan Fasilitas Belajar dalam Meningkatan Prestasi Belajar Siswa Sekolah Menengah Kejuruan. Jurnal MANAJERIAL.

Handoyono, N. A., \& Rabiman, R. (2020). Development of android-based learning application in EFI materials for vocational schools. Journal of Physics: Conference Series.

Handoyono, Nurcholish Arifin. (2019). Development of Media Trainer Kit Charging System to Improve Effectiveness Automotive Electrical Practices. Journal of Mechanical Engineering Education.

Handoyono, Nurcholish Arifin, \& Arifin, Z. (2016). Pengaruh Inquiry Learning dan Problem-Based Learning terhadap Hasil Belajar Pkkr Ditinjau dari Motivasi Belajar. Jurnal Pendidikan Vokasi.

Handoyono, Nurcholish Arifin, \& Hadi, S. (2018). Pengembangan modul pembuatan bodi kendaraan dari fiberglass untuk mendukung Perkuliahan cat dan bodi Kendaraan. Taman Vokasi, 6(1), 36-44.

Kurt, S. (2017). ADDIE Model: Instructional Design.

Maryanti, N., \& Apriana, D. (2019). Kompetensi Siswa SMK dalam Menyongsong Revolusi Industri

4.0. Prosiding Seminar Nasional Pendidikan Program Pascasarjana Universitas PGRI Palembang.

PH, S. P. (2013). Pengembangan SMK Model untuk Masa Depan. Jurnal Cakrawala Pendidikan, $32(1), 14-26$.

Smaldino, S. E., Lowther, D. L., \& Mims, C. (2015). Instructional Media and Technology for Learning. In International Journal of Distributed and Parallel Systems (11th ed.).

Sudarsono, B. (2020). Pengembangan alat tambal ban portable sebagai media pembelajaran siswa SMK. TAMAN VOKASI. https://doi.org/10.30738/jtv.v8i1.7627

Sugiyono. (2014). Metode Penelitian Pendidikan Pendekatan Kuantitatif, Kualitatif, dan R\&D. Bandung: Alfabeta.

Sunarto, S., \& Supriadi, D. (2019). Efektivitas Implementasi Model Pembelajaran SMK dalam Memenuhi Tantangan Revolusi Industri 4.0. TAMAN VOKASI. 